Ю.І. Романенко

Державний заклад «Луганський державний медичний університет», Рубіжне

\title{
Особливості больового синдрому у пацієнтів із мігренню без аури та з хронічною мігренню
}

Мета - вивчити особливості больового синдрому у пацієнтів із мігренню без аури та з хронічною мігренню. Об'єкт іметоди дослідження. Обстежено 31 пацієнта (11 чоловіків та 20 жінок, середній вік Ме $\left(Q_{1}-Q_{3}\right)$ 49(40-52) років) з мігренню без аури (1-ша група, $n=20)$ та хронічною мігренню (2-га група, $n=11)$. Проводили клініко-неврологічне обстеження, пальпацію перикраніальних та шийних м'язів з обох боків із вирахуванням числа болючості перикраніальних м'язів (ЧБПМ) і числа болючості м'язів шиї (ЧБМШ) для кожного пацієнта та їх середнє значення у групі. Визначено суб'єктивну вираженість болю за візуальною аналоговою шкалою (ВАШ), якісну характеристикуголовного болю(ГБ). Результати. За інтенсивністю ГБ за ВАШ пацієнти суттєво не відрізнялися, показник був у межах помірного. В обох групах при дослідженні перикраніальних та шийних м'язів з обох боків болючість при пальпації була від слабкої до помірної, крім скроневого та ремінного м'язів шиї справа, ремінного м'яза голови та трапецієподібного м'яза зліва у пацієнтів 2-ї групи, де болючість мала характер від помірної до вираженої. Показники ЧБПМ та ЧБМШ у 1-й групі зліва та справа були в межах слабкої - помірної, у 2-й групі - помірної - вираженої хворобливості. У пацієнтів 1-ї групи показники, що описують сенсорні та психоемоційні характеристики ГБ, статистично значуще перевищували такі пацієнтів 2-ї групи. У пацієнтів 1-ї групи виявлені прямі кореляційні зв'язки між показником інтенсивності ГБ за ВАШ та афективними характеристиками ГБ, даними евалюативної шкали, в той час як пацієнти 2-ї групи демонструють прямі кореляційні зв'язки між афективними характеристиками ГБ, даними евалюативної шкали та показниками болючості перикраніальних та шийних м'язів. Висновки. Наявність м'язової болючості, сенсорні та психоемоційні характеристики ГБ необхідно враховувати при плануванні лікувальних та реабілітаційних стратегій, що перешкоджатиме прогресуванню та хронізації ГБ і сприятиме підвищенню якості життя пацієнтів.

Ключові слова: мігрень без аури, хронічна мігрень, болючість перикраніальних м'язів, болючість шийних м'язів, візуальна аналогова шкала, больовий опитувальник Мак-Гілла.

\section{Вступ}

Головний біль (ГБ) - одна з найактуальніших проблем сучасного суспільства. Мігренозний головний біль займає 3-тє місце серед усіх хвороб, які призводять до втрати працездатності як серед чоловіків, так і серед жінок віком $<50$ років та зумовлюють серйозний вплив на соціально-економічне функціонування і якість життя пацієнтів (GBD 2016 Disease and Injury Incidence and Prevalence Collaborators, 2017; Saylor D., Steiner T.J., 2018). Всесвітня організація охорони здоров'я включила мігрень до списку 19 захворювань, які найбільшою мірою порушують соціальну адаптацію пацієнтів (WHO, 2016). Хронічна мігрень (XM) вражає 1-2\% населення в цілому і близько 8\% пацієнтів із мігренню, зазвичай розвивається від епізодичної мігрені з щорічною конверсією близько 3\% (May A., Schulte L.H., 2016).

Феномен м'язового напруження викликає формування м'язово-тонічного синдрому - хворобливого напруження м'язів голови та шиї. A.S. Janani та співавтори (2018) виявили підвищену активність перикраніальних м'язів і м'язів шиї та висловили припущення щодо можливого залучення вищезазначених м'язів до патогенезу мігрені. F. Mongini та співавтори (2005) також припускали, що підвищена м'язова болючість може бути одним із факторів, які можуть сприяти еволюції мігрені у хронічну форму.

Мета - вивчити особливості больового синдрому у пацієнтів із мігренню без аури та ХМ.

\section{Об'єкт і методи дослідження}

Обстежено 31 пацієнта: 11 чоловіків та 20 жінок, середній вік $\mathrm{Me}\left(\mathrm{Q}_{1}-\mathrm{Q}_{3}\right) 49$ (40-52) років з мігренню без аури (МБА) (1-ша група, $\mathrm{n}=20)$ та XM (2-га група, $\mathrm{n=11).} \mathrm{Критеріями} \mathrm{включення} \mathrm{були}$ підписання інформованої згоди на участь у дослідженні, наявність ГБ, який відповідає критеріям мігрені відповідно до Міжнародної класифікації головного болю 3-го перегляду, відсутність тяжкої соматичної патології, зловживання медикаментами. Проводили клініко-неврологічне обстеження, мануальну пальпацію перикраніальних (жувальних, скроневих) та шийних (ремінного м'яза голови та шиї, переднього, середнього, заднього сходового, грудниноключично-соскоподібного, трапецієподібного) м'язів з обох боків з визначенням числа болючості перикраніальних м'язів (ЧБПМ) і числа болючості м'язів шиї (ЧБМШ) для кожного пацієнта та їх середнє значення в групі (Simons D.G., Travell J.G., 1983; Данилов А.Б., 2012). Визначені суб'єктивна вираженість ГБ методом візуальної аналогової шкали (ВАШ) (Breivik H. et al., 2008), якісна характеристика ГБ за допомогою больового опитувальника МакГілла з підрахунком індексу числа вибраних дескрипторів (ІЧВД) і рангового індексу болю (РІБ) для сенсорної та афективної шкал, евалюативного показника (Melzack R., 1975).

Статистичну обробкуданих проводили з використанням програми «SPSS 17.0» та «Microsoft Excel for Windows» (2013). Оцінювали достовірні відмінності за допомогою непараметричного критерію Манна - Уїтні для незалежних груп, проводили аналіз рангових кореляцій за Спірменом. Дані представляли у вигляді

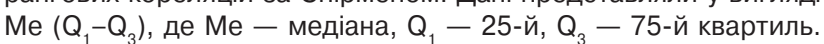
Критичний рівень значущості при перевірці статистичних гіпотез приймали рівним 0,05 .

\section{Результати та їх обговорення}

За інтенсивністю ГБ за ВАШ пацієнти суттєво не відрізнялися, показник був у межах помірного: $\mathrm{Me}\left(\mathrm{Q}_{1}-\mathrm{Q}_{3}\right) 6,00(5,33-6,95)$ у 1 -й та 6,00 (4,70-6,90) - у 2-й групі. Результати мануального дослідження скелетних м'язів голови та шиї пацієнтів представлені в табл. 1. Показники ЧБПМ та ЧБМШ у 1-й групі зліва та справа були в межах слабкої/помірної, у 2-й групі - помірної/вираженої хворобливості, що зіставне з даними A.S. Janani та співавторів (2018). При проведенні міжгрупового порівняння виявлено статистично значуще перевищення лише показника ЧБПМ зліва у 2-й групі $(p=0,016)$, при порівнянні інших показників достовірних відмінностей не відзначено. 
Таблиця 1. Представленість ЧБПМ і чБМШ в обстежених групах

\begin{tabular}{|c|c|c|c|c|}
\hline \multirow{2}{*}{ Показник } & \multicolumn{2}{|c|}{ 1-ша група $(n=20) \operatorname{Me}\left(Q_{1}-Q_{3}\right)$} & \multicolumn{2}{|c|}{ 2-га група $(n=11) \mathrm{Me}\left(Q_{1}-Q_{3}\right)$} \\
\hline & зліва & справа & зліва & справа \\
\hline ЧБПМ, балів & $1,00(0,00-1,50)^{*}$ & $1,00(0,50-2,00)$ & $1,50(0,50-2,50)$ & $1,00(0,50-2,00)$ \\
\hline ЧБМШ, балів & $1,40(0,05-1,60)$ & $0,50(0,20-1,90)$ & $2,00(1,40-2,60)$ & $1,60(1,00-2,00)$ \\
\hline
\end{tabular}

Рівень істотності відмінності р<0,01 при порівнянні пацієнтів відповідних груп: *при порівнянні пацієнтів 1-ї та 2-ї груп зліва.

Таблиця 2. Результати тестування за опитувальником Мак-Гілла

\begin{tabular}{|c|c|c|c|c|c|}
\hline \multicolumn{6}{|c|}{ Показник } \\
\hline \multirow{2}{*}{ Група } & \multicolumn{2}{|c|}{ ІЧВД, $\mathrm{Me}\left(Q_{1}-Q_{3}\right)$} & \multicolumn{2}{|c|}{ PIБ, $\operatorname{Me}\left(Q_{1}-Q_{3}\right)$} & \multirow{2}{*}{$\begin{array}{c}\text { Евалюативна шкала } \\
M e(Q 1-Q 3)\end{array}$} \\
\hline & сенсорний & афективний & сенсорний & афективний & \\
\hline 1-ша & $9,00(7,00-11,00)^{*}$ & $5,00(4,00-6,00)^{\star}$ & $20,50(18,25-25,00)^{*}$ & $9,50(7,25-13,00)^{*}$ & $4,00(4,00-5,00)^{*}$ \\
\hline 2-га & $7,00(5,00-8,00)$ & $3,00(2,00-5,00)$ & $15,00(9,00-19,00)$ & $6,00(5,00-9,00)$ & $3,00(3,00-4,00)$ \\
\hline
\end{tabular}

*Рівень істотності відмінності р>0,05 при порівнянні відповідних показників пацієнтів 1-ї та 2-ї груп.

За даними больового опитувальника Мак-Гілла пацієнти 1-ї групи порівняно з 2-ю групою емоційніше описують свій ГБ та використовують більше дескрипторів для сенсорної та афективної характеристики ГБ. Так, для сенсорної характеристики болю $\geqslant 6$ дескрипторів (із 13 можливих) використовували в 1,3 раза, $\geqslant 10-$ у 2,5 раза частіше. Для характеристики болю на психоемоційному рівні (за даними афективної шкали) $\geqslant 4$ дескрипторів (із 6 можливих) використовували у 2,5 раза, максимально можливе число дескрипторів - у 3,3 раза частіше. За евалюативною шкалою інтенсивність болю від сильного до нестерпного також зареєстрована в 1,2 раза частіше. Результати тестування за опитувальником Мак-Гілла наведено в табл. 2. При проведенні міжгрупового порівняння в 1-й групі виявлено достовірне перевищення показників ІЧВДдля сенсорної ( $p=0,023$ та афективної шкали $(p=0,023)$, РІБ для сенсорної $(p=0,016)$ та афективної шкали $(p=0,005)$ та інтенсивності болю за евалюативною шкалою $(p=0,025)$.

У 1-й групі виявлено статистично значущий кореляційний зв'язок між показником ВАШ та ІЧВД для афективної шкали $(r=0,538 ; p=0,014)$, РІБ для афективної шкали $(r=0,573 ; p=0,008)$ та даними евалюативної шкали $(r=0,532 ; p=0,016)$. У 2-й групі статистично значущий кореляційний зв'язок виявлено між показником ІЧВД для афективної шкали та ЧБМШ зліва ( $r=0,760$; $p=0,018)$, ЧБПМ справа ( $r=0,822 ; p=0,007)$, між показником РІБ для афективної шкали та ЧБМШ зліва $(r=0,806 ; p=0,009)$, ЧБПМ справа ( $r=0,865 ; p=0,003)$, між показником евалюативної шкали та ЧБПМ справа ( $r=0,696 ; p=0,037)$, що може свідчити на користь складніших патогенетичних механізмів та залучення перикраніальних та шийних м'язів у формування алгічного синдрому при XМ і зіставне з даними досліджень (Mongini F. et al., 2005; Hagen K. et al., 2012; Hung Ch.l. et al., 2016).

\section{Висновки}

Наявність м'язової болючості, сенсорні та психоемоційні характеристики болю необхідно враховувати при плануванні лікувальних та реабілітаційних стратегій, що перешкоджатиме прогресуванню та хронізації ГБ та сприятиме підвищенню якості життя пацієнтів.

\section{Список використаної літератури}

Данилов А.Б. (2012) Диагностика и лечение фибромиалгии. Леч. врач, 5: $30-34$.

Breivik H., Borchgrevink P.C., Allen S.M. et al. (2008) Assessment of pain. Br. J. Anaesth., 101(1): 17-24.

GBD 2016 Disease and Injury Incidence and Prevalence Collaborators (2017) Global, regional, and national incidence, prevalence, and years lived with disability for 328 diseases and injuries for 195 countries, 1990-2016: a systematic analysis for the Global Burden of Disease Study 2016. Lancet, 390(10100): 1211-1259.

Hagen K., Linde M., Steiner T.J. et al. (2012) The bidirectional relationship between headache and chronic musculoskeletal complaints: an 11-year follow-up in the Nord-Trøndelag Health Study (HUNT). Eur. J. Neurol., 19(11): 1447-1454.

Hung Ch.I., Liu Ch.Y., Yang Ch.H., Wang Sh.J. (2016) Headache: an important factor associated with muscle soreness/pain at the two-year follow-up point among patients with major depressive disorder. J. Headache Pain, 17: 57.

Janani A.S., Pope K.J., Fenton N. (2018) Resting cranial and upper cervical muscle activity is increased in patients with migraine. Clin. Neurophysiol., 129(9): 1913-1919.

May A., Schulte L.H. (2016) Chronic migraine: risk factors, mechanisms and treatment. Nat. Rev. Neurol., 12(8): 455-464.

Melzack R. (1975) The McGill Pain Questionnaire: major properties and scoring methods. Pain, 1(3): 277-299.
Mongini F., Deregibus A., Rota E. (2005) Psychiatric disorders and muscle tenderness in episodic and chronic migraine. Expert. Rev. Neurother., 5(5): 635-642.

Saylor D., Steiner T.J. (2018) The Global Burden of Headache. Semin. Neurol., 38(2): 182-190.

Simons D.G., Travell J.G. (1983) Myofascial Pain and Dysfunction: The Trigger Point Manual. Williams \& Wilkins, Baltimore/London, $713 \mathrm{p}$.

WHO (2016) Headache disorders (http://www.who.int/mediacentre/factsheets/ fs277/en/)

\section{Особенности болевого синдрома у пациентов с мигренью без ауры и с хронической мигренью}

\section{ю.и. Романенко}

Резюме. Цель - изучить особенности болевого синдрома у пациентов с мигренью без ауры и с хронической мигренью. Объект и методыисследования. Обследован 31 пациент (11 мужчин и 20 женщин, средний возраст $\mathrm{Me}\left(Q_{1}-Q_{3}\right) 49$ (40-52) лет) с мигренью без ауры (1-я группа, $n=20)$ и хронической мигренью (2-я группа, $n=11)$. Проводили клинико-неврологическое обследование, пальпацию перикраниальных и шейных мышц с обеих сторон с подсчетом числа болезненности перикраниальных мышц (ЧБПМ) и числа болезненности мышц шеи (ЧБМШ) для каждого пациента и их среднее значение в группе. Определена субъективная выраженность боли методом визуальной аналоговой шкалы (ВАШ), качественная характеристика головной боли (ГБ). Результаты. По интенсивности ГБ по ВАШ пациенты существенно не отличались, показатель был в пределах умеренного. В обеих группах при исследовании перикраниальных и шейных мышц с обеих сторон болезненность при пальпации была в пределах от слабой до умеренной, кроме височной и ременной мышц шеи справа, ременной мышцы головы и трапециевидной мышцы слева у пациентов 2-й группы, где болезненность имела характер от умеренной до выраженной. Показатели ЧБПМ и ЧБМШ в 1-й группе слева и справа были в пределах слабой - умеренной болезненности, во 2-й группе - от умеренной до выраженной. У пациентов 1-й группы показатели, описывающие сенсорные и психоэмоциональные характеристики ГБ, статистически значимо превышали таковые 2-й группы. У пациентов 1-й группы выявлены прямые корреляционные связи междупоказателем интенсивности ГБ по ВАШ и аффективными характеристиками ГБ, данными эвалюативной шкалы, в то время какпациенты 2-й группы демонстрировали прямые корреляционные связи между аффективными характеристиками ГБ, данными эвалюативной шкалы и показателями болезненности перикраниальных и шейных мышц. Выводы. Наличие мышечной болезненности, сенсорные и психоэмоциональные характеристики ГБ необходимо учитывать при планировании лечебных и реабилитационных стратегий, что будет препятствовать прогрессированию и хронизации ГБ и способствовать повышению качества жизни пациентов.

Ключевые слова: мигрень без ауры, хроническая мигрень, болезненность перикраниальных мышц, болезненность шейных мышц, визуальная аналоговая шкала, болевой опросник Мак-Гилла.

\section{Features of the pain syndrome in patients with migraine without aura and chronic migraine \\ Yu.I. Romanenko}

Summary. Aim - to study the peculiarities of pain syndrome in patients with migraine without aura and chronic migraine. The object and methods 
of research. A total of 31 patients ( 11 men and 20 women, average age $\operatorname{Me}\left(Q_{1}-Q_{3}\right) 49(40-52)$ years) with migraine without aura (1 $1^{\text {st }}$ group, $n=20$ ) and chronic migraine $\left(2^{\text {nd }}\right.$ group, $\left.n=11\right)$ were examined. Clinical neurological examination, palpation of the pericranial and cervical muscles on both sides were carried out, counting the number of tenderness of the pericranial muscles (NTPM) and the number of tenderness of the neck muscles (NTNM) for each patient and their average score in the group; subjective severity of pain was determined with visual analogue scale (VAS) and the qualitative characteristics of headache were identified. Results. Data by the VAS in both groups did not differ significantly, the values were moderate. In both groups, in the study of pericranial and cervical muscles on both sides, pain during palpation ranged from weak to moderate, except for the temporal and belt muscles of the neck on the right side, the belt muscle of head and trapezoid muscle on the left side in patients of group II, where the pain was moderate to severe. The scores of NTPM and NTNM in $1^{\text {st }}$ group on the left and right sides were within the limits of mild to moderate pain, while in $2^{\text {nd }}$ group, they ranged from moderate to severe. In patients of the 1st group, the indicators describing the sensory and psycho-emotional characteristics of headache were statistically significantly higher than similar data from $2^{\text {nd }}$ group. Patients of $1^{\text {st }}$ group found to have direct correlation between the intensity of pain by VAS and affective characteristics of headache, data of the evaluational scale, while patients of $2^{\text {nd }}$ group show direct correlation between the affective characteristics of headache, data of the evaluative scale and number of tenderness of the pericranial and cervical muscles. Conclusions. The presence of muscle pain, sensory and psycho-emotional characteristics of headache must be considered when planning treatment and rehabilitation strategies, which will prevent the progression and chronicity of headache and help to improve the quality of life of the patients.

Key words: migraine without aura, chronic migraine, pericranial muscles tenderness, neck muscle tenderness, visual analog scale, McGill pain questionnaire.

\section{Адреса для листування:}

Романенко Юрій Ігорович

93012, м. Рубіжне, вул. Будівельників, 32

Державний заклад «Луганський державний медичний університет»,

кафедра неврології, психіатрії та наркології

E-mail: romanenko.yuri@gmail.com

Одержано 10.01.2019 